\title{
Effects of Dimethoate on Some Haematological Parameters in Heterobranchus longifilis in the Laboratory
}

\author{
Wilfred-Ekprikpo P.C. \\ Aquaculture Department, Nigerian Institute for Oceanography and Marine Research, 3, Wilmot Point Road, \\ Victoria Island, PMB 12729, Lagos, Nigeria
}

*Corresponding Author: Wilfred-Ekprikpo P.C, Aquaculture Department, Nigerian Institute for Oceanography and Marine Research, 3, Wilmot Point Road, Victoria Island, PMB 12729, Lagos, Nigeria

\begin{abstract}
The haematological changes in Heterobranchus longifilis exposed to sub-lethal concentrations of dimethoate were investigated. A total of 60 H.longifilis (mean length $27.81 \pm 2.09 \mathrm{~cm}$; mean weight $386.77 \pm 56.23 \mathrm{~g})$, were exposed using static renewal assay to different concentrations $(0.00,0.25,0.50,0.75$ and $1.00 \mathrm{mg} / \mathrm{L}$ ) of dimethoate for 15 days. The experiment evaluated the sub-lethal effects of the exposure on some haematological parameters including Haemoglobin $(\mathrm{Hb})$, Red blood cell $(\mathrm{RBC})$, packed cell volume $(P C V)$, white blood cell (WBC), and differential counts such as neutrophils, lymphocytes, monocytes, mean corpuscular haemoglobin concentration $(M C H C)$, mean corpuscular volume $(M C V)$ and oxygen carrying capacity $(O C C)$. The results showed a significant $(P<0.05)$ reduction in the values of $H b, R B C, P C V$, lymphocytes, MCHC, and OCC, with increasing concentrations of the toxicant. However, exposure of $H$. longifilis to dimethoate caused significant elevation in the values of WBC, neutrophils, monocytes, MCV and $\mathrm{MCH}$ when compared to the control values. Exposure of this specie to sub lethal levels of this chemical altered some components of its haematological variables, which may lead to abnormal metabolism of the fish. Therefore, there is need for proper disposal of domestic wastes containing pesticides into the aquatic environment.
\end{abstract}

Keywords: Fish, Blood variable, Contaminants, Aquatic Environment, Stress

\section{INTRODUCTION}

The natural environment is polluted with various types of anthropogenic contaminants majorly from domestic, industrial and agricultural activities [1]. In recent years, the widespread use of agrochemicals to meet the agricultural demand of food production for the populace is expected. This has led to intensive and indiscriminate use of these agrochemicals, which results in the contamination of the aquatic ecosystems [2]. Consequent of continuous and arbitrary use of various types of pesticides in the field, water bodies are incessantly getting contaminated on a regular basis through run offs [3]. Aquatic pollution consequent of pesticides applications has become a critical issue especially in the developing nations of the world. Direct or indirect pollution of water by pesticides can lead to fish death, and reduction in fish population and productivity in the aquatic environment [4]. Apart from the instant warnings of mortality that may be obvious in the event of water pollution in cases of acute toxicity, however, organisms are subjected to long term effects consequent of chronic exposure which may also prove to be fatal to the organism or as toxicants to the final consumers of such organism [5, 6].

Since, water contamination by pesticides affect the aquatic system and affect the fish health, hence, it is important to examine the toxic effects of pesticides on fish. Toxic effects of pesticides on aquatic organisms can be investigated by testing the changes in haematological parameters [7]. Studies have shown that when the water quality is affected by toxicants, any physiological change will be reflected in the values of one or more of the haematological parameters [8]. This is because blood is a pathophysiological reflector of the whole body and therefore blood variables are necessary in establishing the structural and functional significance of fish exposed to contaminants [9]. However, reports on chronic toxicity of chemicals shows that chronic levels can cause changes in blood composition of fish without resulting in fish mortality [10,11],. 
Furthermore, it was reported that the blood variables of investigative importance include red blood cell, while blood cell, haemoglobin, packed cell volume and differential counts[12]. These parameters can easily be evaluated and would readily respond to incidental factor such as physical and environment stress consequent of water pollution induced by pesticides [13, 14]. Conversely, some authors $[15,16]$ have reported a reduction in the values of packed cell volume, haemoglobin and red blood cells values of some fish after their exposure to pesticides. The information indicates that haematological parameters could be used as prospective biomarkers of pesticides exposure. Moreover, haematological parameters indicate the internal conditions of fish under stress more quickly than other commonly measured parameters as they respond quickly to changes in environmental conditions $[17,18]$. Therefore the objective of the present study was to investigate the haematological changes in H.longifilis exposed to different concentrations of dimethoate.

\section{Materials ANd Methods}

\subsection{Experimental Location and Fish}

The study was carried out in Aqua Green Integrated Aquaculture Center, Eliozu, Port Harcourt, Rivers State, Nigeria. A total of 60 H.longifilis (mean length $27.81 \pm 2.09 \mathrm{~cm}$; mean weight $386.77 \pm 56.23 \mathrm{~g}$ ) were sourced from a fish farm in the State. The fishes were transported in two open 501 containers to the laboratory and acclimated for a period of seven days.

\subsection{Preparation of Test Solution}

Dimethoate, used in this experiment was purchased from a commercial outlet in Port Harcourt, Nigeria.. 10mg were weighed using a sensitive weighing balance (Sartorius Balance, model H2013, Portugal). Stock solution of the detergents was then prepared by dissolving each $10 \mathrm{mg}$ in $1000 \mathrm{ml}$ of distilled water. Appropriable graded concentrations were made by serial dilutions. The desired toxicant concentrations $0.5,1.00,1.50,2.002 .50 \mathrm{mg})$ and a control $(0.00 \mathrm{mg} / \mathrm{l})$ with no toxicants prepared according to the method described by [19].

\subsection{Exposure of Fish}

H.longifilis were exposed to the chemical at the concentrations of 0.00 control, $0.25,0.50,0.75$ and $1.00 \mathrm{mg} / \mathrm{L}$ in triplicates. Four fish were randomly distributed into each test tank. The experiment lasted for a period of 15 days. The water in the tanks was exchanged on daily basis. The fish were fed two times in a day at $3 \%$ body weight with Vital fish feed.

\subsection{Evaluation of Physico-Chemical Parameters of Water in Experimental Tanks}

During the exposure period which lasted for 15 days, some water quality parameters namely $\mathrm{pH}$, dissolved oxygen, temperature and ammonia were taken daily using the methods described by APHA [20].

\subsection{Collection of Blood and Analysis}

At the end of the exposure, blood samples were collected for haematological analysis.

Haematological analysis procedures described by Blaxhall and Daisley [21] were used in the assessment of the various blood parameters or otherwise stated. Both the Red blood cell (RBC) and white blood cell (WBC) were evaluated using improved Neubauer counter [22]. The packed cell volume (PCV) was determined using micro haematocrit tubes after centrifuging for five minutes. The hemoglobin content of the blood was assessed by cyanomethaemoglobin method. The values of thrombocytes were determined using the Rees and Beeker method [23]. The differential counts for cells (neutrophils, lymphocytes, eosinophils and monocytes) were evaluated by dropping thoroughly mixed blood film on clean microscope slides and allowed to dry. The slides were thereafter fixed in methanol and stained with leishman stain. The counting was done based on different cell types and recorded. The values of haematological indices were calculated using the formulae described by Miale [24].

$\mathrm{OCC}=\mathrm{Hb} \times 1.25$ 
$\mathrm{MCV}=\frac{H C T}{R B C} \times 10$

$\mathrm{MCH}=\frac{H b}{R B C} \times 10$

$\mathrm{MCHC}=\frac{H b}{P C V} \times 100$

\subsection{Statistical Analysis}

Data obtained from the study were subjected to a one-way analysis of variance (ANOVA) test at $0.05 \%$ probability level, using statistical package for the social sciences (SPSS) version 17 . Where differences among means existed, the Tukey test was used.

\section{RESUlts}

The water quality variables in the experimental tanks of H.longifilis exposed to dimethoate indicated a concentration dependent change in the values of ammonia, dissolved oxygen and nitrites (Table 1). These values were altered significantly $(\mathrm{P}<0.05)$ when compared to the control values (Table 1$)$. The haematological changes produced by the effects of dimethoate in H.longifilis, showed a concentration dependent reduction in the values of $\mathrm{Hb}$ from $6.91 \pm 0.66$ in the control, to $3.47 \pm 0.77 \mathrm{~g} / \mathrm{dl}$ at $1.00 \mathrm{mg} / \mathrm{L}$ concentration of the chemicals. The values of RBC equally reduced from $5.02 \pm 0.55$ in the control, to $2.85 \pm 0.07$ at $1.00 \mathrm{mg} / \mathrm{L}$ concentration. Also, the same trend was observed in PCV which reduced significantly $(\mathrm{P}<0.05)$ from $30.99 \pm 1.98 \%$ to $20.89 \pm 2.99 \%$ at $1.00 \mathrm{mg} / \mathrm{l}$ of the chemical. Moreover, significant reductions $(\mathrm{P}<0.05)$ comparable to the control values were similarly recorded in lymphocytes. Conversely, concentration dependent elevations were recorded in WBC, neutrophils and monocytes of the exposed fish (Table 2). The results of the red blood cell indices was shown in Table 3: consistent reductions relative to the concentrations of the chemical was recorded in the values of MCHC, and OCC, however, no definite trend was observed in the values of $\mathrm{MCH}$ and MCB across all the concentrations (Table 3).

Table1. Physico-Chemical Parameters of Water in Experimental Tanks (Meant $\pm S D$ )

\begin{tabular}{|l|l|l|l|l|l|}
\hline \multirow{2}{*}{ Parameters } & \multicolumn{5}{|c|}{ Concentrations $(\mathbf{m g} / \mathbf{L})$} \\
\cline { 2 - 6 } & $\mathbf{0 . 0 0}$ & $\mathbf{0 . 2 5}$ & $\mathbf{0 . 5 0}$ & $\mathbf{0 . 7 5}$ & $\mathbf{1 . 0 0}$ \\
\hline Temperature $\left({ }^{0} \mathrm{C}\right)$ & $28.09 \pm 1.88^{\mathrm{a}}$ & $28.96 \pm 1.87^{\mathrm{a}}$ & $29.11 \pm 1.07^{\mathrm{a}}$ & $28.61 \pm 1.99^{\mathrm{a}}$ & $28.61 \pm 1.66^{\mathrm{a}}$ \\
\hline $\mathrm{pH}$ & $6.47 \pm 1.77^{\mathrm{a}}$ & $6.43 \pm 1.82^{\mathrm{a}}$ & $6.42 \pm 1.99^{\mathrm{a}}$ & $6.44 \pm 1.91^{\mathrm{a}}$ & $6.41 \pm 1.57^{\mathrm{a}}$ \\
\hline Ammonia $(\mathrm{mg} / \mathrm{l})$ & $0.17 \pm 0.02^{\mathrm{a}}$ & $0.44 \pm 0.06^{\mathrm{b}}$ & $0.47 \pm 0.02^{\mathrm{b}}$ & $0.47 \pm 0.03^{\mathrm{b}}$ & $0.57 \pm 0.02^{\mathrm{c}}$ \\
\hline DO $(\mathrm{mg} / \mathrm{l})$ & $6.68 \pm 0.02^{\mathrm{c}}$ & $6.40 \pm 0.12^{\mathrm{c}}$ & $5.67 \pm 0.14^{\mathrm{b}}$ & $4.11 \pm 0.14^{\mathrm{a}}$ & $4.13 \pm 0.67^{\mathrm{a}}$ \\
\hline Nitrite $(\mathrm{mg} / \mathrm{l})$ & $0.03 \pm 0.01^{\mathrm{a}}$ & $0.08 \pm 0.01^{\mathrm{b}}$ & $0.08 \pm 0.01^{\mathrm{b}}$ & $0.09 \pm 0.01^{\mathrm{c}}$ & $0.09 \pm 0.01^{\mathrm{c}}$ \\
\hline
\end{tabular}

Means within the same row with different superscripts are significantly different $(P<0.05)$

Table2. Haematological Parameters of H.longifilis Exposed to Different Concentrations of Dimethoate (Mean $\pm S D)$

\begin{tabular}{|c|c|c|c|c|c|}
\hline \multirow[t]{2}{*}{ Parameters } & \multicolumn{5}{|c|}{ Concentrations (mg/L) } \\
\hline & 0.00 & 0.25 & 0.50 & 0.75 & 1.00 \\
\hline $\mathrm{Hb}$ & $6.91 \pm 0.66^{\mathrm{a}}$ & $6.02 \pm 0.181^{\mathrm{a}}$ & $5.27 \pm 0.77^{\mathrm{b}}$ & $4.15 \pm 0.77^{b}$ & $3.47 \pm 0.77^{\mathrm{c}}$ \\
\hline $\mathrm{RBC}$ & $5.02 \pm 0.55^{\mathrm{c}}$ & $4.75 \pm 0.31^{\mathrm{c}}$ & $4.01 \pm 0.88^{b}$ & $3.55 \pm 0.99^{\mathrm{b}}$ & $2.85 \pm 0.07^{\mathrm{a}}$ \\
\hline PCV & $30.99 \pm 1.98^{a}$ & $28.88 \pm 1.99^{a}$ & $25.09 \pm 1.99^{b}$ & $21.60 \pm 1.92^{b}$ & $20.89 \pm 2.99^{c}$ \\
\hline WBC & $17.88 \pm 1.99^{\mathrm{a}}$ & $19.99 \pm 1.56^{\mathrm{a}}$ & $24.69 \pm 0.88^{b}$ & $27.97 \pm 1.72^{b}$ & $30.99 \pm 1.57^{\mathrm{c}}$ \\
\hline NEUT & $17.00 \pm 2.88^{\mathrm{a}}$ & $23.77 \pm 1.88^{\mathrm{b}}$ & $29.72 \pm 3.47^{b}$ & $34.87 \pm 4.77^{\mathrm{c}}$ & $37.23 \pm 7.97^{\mathrm{d}}$ \\
\hline LYM & $78.62 \pm 9.99^{\mathrm{a}}$ & $69.36 \pm 9.89^{\mathrm{a}}$ & $61.61 \pm 8.95^{\mathrm{b}}$ & $52.35 \pm 7.97^{\mathrm{c}}$ & $47.89 \pm 5.88^{c}$ \\
\hline $\mathrm{MON}$ & $4.38 \pm 1.02^{\mathrm{a}}$ & $6.87 \pm 1.87^{\mathrm{a}}$ & $8.67 \pm 2.87^{\mathrm{a}}$ & $12.78 \pm 2.55^{b}$ & $14.88 \pm 4.88^{b}$ \\
\hline
\end{tabular}

Means within the same row with different superscripts are significantly different $(P<0.05)$

Key: PCV-Hb-Haemoglobin (g/dL); RBC-Red Blood Cell (Cells X10 $10 / L)$; Packed Cell Volume (\%); WBCWhite Blood Cell (Cells $\left.\times 10^{8} / \mathrm{L}\right)$; PLT-Platelets (Cells x109/L); NEUT-Neutrophils (\%); LYM- Lymphocytes (\%); MON-Monocytes (\%). 
Effects of Dimethoate on Some Haematological Parameters in Heterobranchus longifilis in the Laboratory

Table3. Red Blood cell Indices of H.longifilis Exposed to Different Concentrations of Dimethoate (Mean $\pm S D)$

\begin{tabular}{|l|l|l|l|l|l|}
\hline MCHC & $22.30 \pm 4.97^{\mathrm{a}}$ & $20.85 \pm 3.01^{\mathrm{a}}$ & $21.00 \pm 3.11^{\mathrm{a}}$ & $19.21 \pm 3.06^{\mathrm{b}}$ & $16.67 \pm 2.77^{\mathrm{b}}$ \\
\hline MCH & $13.77 \pm 3.99^{\mathrm{a}}$ & $12.67 \pm 2.69^{\mathrm{b}}$ & $13.14 \pm 3.92^{\mathrm{b}}$ & $11.72 \pm 3.77^{\mathrm{c}}$ & $12.18 \pm 2.56^{\mathrm{c}}$ \\
\hline MCV & $61.73 \pm 8.99^{\mathrm{a}}$ & $60.80 \pm 7.04^{\mathrm{a}}$ & $62.56 \pm 9.07^{\mathrm{a}}$ & $60.84 \pm 9.06^{\mathrm{a}}$ & $73.29 \pm 9.99^{\mathrm{a}}$ \\
\hline OCC & $8.69 \pm 1.88^{\mathrm{a}}$ & $7.53 \pm 1.75^{\mathrm{a}}$ & $6.59 \pm 1.99^{\mathrm{b}}$ & $5.19 \pm 1.69^{\mathrm{b}}$ & $4.34 \pm 1.66^{\mathrm{a}}$ \\
\hline
\end{tabular}

Means within the same row with different superscripts are significantly different $(P<0.05)$

Key: MCH-Mean Corpuscular Haemoglobin (pg); MCHC-Mean Corpuscular Haemoglobin Concentration (g/dL); MCV-Mean Corpuscular Haemoglobin (fL); OCC-Oxygen Carrying Capacity ( $g / d L)$

\section{DISCUSSION}

The water quality parameters recorded in the experimental tanks were within the same range except in ammonia, nitrite and dissolved oxygen levels. This result agrees with the previous observation by Akinrotimi et al.[25], who demonstrated that cypermethrin caused some notable alterations in the physico-chemical parameters of water in the experimental tanks of fish during exposure. This may be due to stress induced mucus secretion from the skin of the fish and wastes elimination through the vent, which is release into the water, thereby increasing its nitrite and ammonia level and consequently reducing the dissolved oxygen levels.

Changes in haematological parameters in the treated fish might have been brought about by its exposure to different concentrations of dimethoate which induce an anaemic condition due to decreased synthesis of $\mathrm{Hb}$ and $\mathrm{RBC}$ number in hemopoietic organs. The reduction of $\mathrm{RBC}$ and $\mathrm{Hb}$ as observed in this study aligns with the findings of Nte et al. [26] in Sarotherodon melanotheron exposed to industrial effluents. This reduction may be due to development of hypoxic condition during the exposure which eventually leads to increase in destruction of RBC or decrease in rate of formation of RBC due to non availability of $\mathrm{Hb}$ content in cellular medium [27]..The damaging effects of contaminants on erythrocytes may be an outcome of its action on erythropoietic tissues, which leads to failure in generation of red cells [28]. Conversely, Akani and Gabriel [29] reported that decrease in RBC and its parameters is attributed to decreased erythropoietic activity which in most vertebrates, including fishes is regulated by the erythropoietin produced in the kidney.

In this study, the values of WBC in the exposed fish, increased with increasing concentrations of the chemical. This result is similar with the report of Akinrotimi et al. [30]. The increase may be due to their role by stimulating the haemopoietic tissues and the immune system by producing antibodies and chemical substances working as defense against infection[31]. It indicates that fish can develop a defensive mechanism to overcome the toxic stress. The present study suggested that the perturbations in these blood indices attributed to a defense reaction against toxicity of dimethoate through the stimulation of erythropoesis or may be due to the disturbances that occurred in both metabolic and haemopoetic activities of fish exposed to below safe concentrations of the chemical [32].

A significant decline in lymphocyte count and a marked increase in neutrophils and monocytes in the exposed fish were observed. This agrees with the report of George et al. [32], in Clarias gariepinus exposed to atrazine. An increase in the number of neutrophils and reduction in lymphocytes have also been reported in Tilapia guineensis treated with industrial effluents [33]. The reductions in lymphocyte and rise in neutrophil content could be due to the destruction of haematopoetic tissue and decrease in non-specific immune system due to increased concentration of defensive poison. The increase in the number of monocytes in present study may be due to toxic effects of dimethoate on the kidney and spleen [34].

Mean corpuscular volume (MCV) gives information about the status or size of RBC [35]. MCV value increased significantly with increasing concentrations of the toxicants. The mean corpuscular haemoglobin $(\mathrm{MCH})$ and mean corpuscular haemoglobin concentration (MCHC) are good indicators of red blood cell swelling or shrinkage, the alterations in the $\mathrm{MCH}$ and $\mathrm{MCHC}$ can be attributed to the blood defense machinery against the toxic effect of the chemical through the stimulation of erythropoiesis in the kidney of the fish [36]. The oxygen carrying capacity of the blood is an indication of quantity of $\mathrm{Hb}$ in the blood which determines the amount of oxygen available to the tissues of the organism, therefore decrease in OCC levels as observed in this study corroborates with the findings of Akinrotimi and Amachree [37], the reduction will impair oxygen supply to the various 
tissues resulting in low energy production and slow metabolic rate. If this condition is allowed for a long time in the presence of the toxicant, the fish will develop blood dyscrasis and degeneration of erythrocytes [38].

\section{CONCLUSION}

Exposure of H.longifilis to different concentrations of dimethoate produces an adverse effect in haematological parameters which affect the normal behaviour of the fish. These changes might be potentially disruptive to the survivability of the fish in their natural environment. The measuring of haematological parameters in the present study provides valuable information which might be useful in the assessment of fish health in fisheries management. The chemical caused a general disorder in the haematology of the fish which is an indication that it is toxic to the fish at sublethal concentrations and so can cause death after prolonged exposure. Therefore its use should be adequately restricted to avoid contact with the aquatic environment.

\section{REFERENCES}

[1] Gabriel, U.U., Uedeme-Naa, B., and Akinrotimi, O.A. (2011a). Pollutant induced altered behaviours in fish: A review of selected literature. Journal of Technology and Education in Nigeria, 16(1): 9-23.

[2] Chandra, S., Ram, R.N. and Singh, I.J. (2001). Toxic effects of Carbofuran on certain haematological parameters in yearlings of Cyprinus carpio. Aquaculture, 2: 137-140.

[3] Agrahari, S., Pandey, K.C. and Gopal, K., (2006). Effect of monocrotophos on erythropoietic activity and hematological parameters of the freshwater fish, Channa punctatus (Bloch). Bull. Environ. Contam. Toxicol. 76: 607-613.

[4] Agarwal, S.K., Pandey, C. and Gopal, G., (2006). Effects of monocrotophos on erythropoetic activity and hematological parameters of Channa punctatus. Bull. Envrn. Contm. Toxicl. 76: 607-613.

[5] Far, M.S., Roodsari, H.V., Zamini, A., Mirrasooli, E. and Kazemi, R., (2012). The effects of diazinon on behavior and some hematological parameters of fry rainbow trout (Oncorhynchus mykiss).W. J. Fish. M Sci. 4: 4369-375.

[6] Jayaprakash, C. and Shettu, N., (2013). Changes in the hematology of the freshwater fish, Channa punctatus (Bloch) exposed to the toxicity of deltamethrin. J. Chem. Pharma. Res. 6: 178-183.

[7] Gabriel, U.U., Akinrotimi, O.A. and Eseimokumo, F. (2011b). Haematological responses of wild Nile tilapia Oreochroimis niloticus after acclimation to captivity. Jordan Journal of Biological Sciences, 4(4): $223-230$.

[8] Gabriel, U.U., Akinrotimi, O.A., and Ariweriokuma, S.V. (2012). Alterations of selected electrolytes in organs of African catfish, Clarias gariepinus treated with cypermethrin. Advances in Students Research, 2(1):53-60.

[9] Adhikari S., Sarkar B., Chatterjee A., Mahapatra C.T. And Ayyappan S (2004).Effects of cypermethrin and carbofuran on certain haematological parameters and prediction of their recovery in a fresh water teleost, Labeo rohita (Hamilton). Ecotoxicology and Environmental Safety 58:220-226.

[10] Akinrotimi, A. O. Gabriel, U.U., Anyanwu, P.E and Anyanwu, A.O. (2007). Influence of sex, Acclimation Methods and Period on Haematology of Sarotherodon melanotheron (cichilidae). Research Journal of Biological Sciences, 2(3), 348-352.

[11] Akinrotimi, O.A., Abu, O.M.G., Ansa, E.J., Edun, O.M., and George, O.S. (2009). Haematological responses of Tilapia guineensis to acute stress. International Journal of National and Applied Sciences 5(3):338 - 343

[12] Akinrotimi, O,A., Abu, O.M.G., Agokei, E.O., and Uedeme-Naa, B. (2010a). Effects of direct transfer to fresh water on the haematological parameters of Tilapia guineensis (Bleeker 1862). Animal Research International 7(2), $1199-1205$.

[13] Akinrotimi, O.A., Uecleme-Naa, B. and Agokei, E.O. (2010b). Effects of acclimation on haematological parameters of Tilapia guineensis. Science World Journal 5(4):1-4.

[14] Akinrotimi, O.A., Abu, O.M.G., Bekbele, D.O., Udeme-Naa, B and Aranyo, A.A. (2010c). Haematological characteristics of Tilapia guineensis from Buguma creek, Niger delta, Nigeria. Electronic Journal of Environmental Agricultural and Food Chemistry, 9(8):1415 - 1422.

[15] Gabriel, U.U., Anyanwu, P.E and Akinrotimi O. A. (2007). Effect of Freshwater Challenge on the Blood Characteristics of Sarotherodon melanotheron. Agricultural Journal, 2(3): 388-391. 
[16] Kori-Siakpere, O. and Ikomi, U. (2011) Alterations in some haematological parameters of the African Snakehead Parachanna africana exposed to Cadmium. Nature Science and Biology 3(4):29-34.

[17] Agarwal K,, Chaturvedi LD (1995). Anomalies in blood corpuscles of Heteropneustes fossilis induced by alachlor and rogor. Adv. Bios. 14: 73-80

[18] Agarwal S.J, and Srivastava A.K. (1980). Haematological responses in a freshwater fish to experimental manganese poisoning. Toxicology 17: 97-100.

[19] Yaji A.J and Auta J (2007) Sublethal effects of monocrotophos on some haernatological indices of African catfish Clarias gariepinus . International Journal of Fisheries 2(1) 115-117.

[20] APHA (1998) Standard Methods for the examination of water and waste water American Public Health Association. 874pp.

[21] Blaxhall, P.C and Daisley K.W (1973) Routine haematological methods for use with fish blood. Journal of Fish Biology 5: 771-781.

[22] Rusia V and Sood SK (1992) Routine haematological test In: Medical laboratory technology Mukerjee, K.L. (ed) Tata McGraw Hill Publishing Company Limited.

[23] Seiverd CE (1964) Haernatology for medical technologists. Lea and Febiger, Philadephia. 946pp.

[24] Miale, J. B. (1982). Laboratory medicine haematology (6th Edn.) The C. V. Mosby Co., London, 883 pp.

[25] Akinrotimi, O.A., Gabriel, U.U., and Ariweriokuma, S.V. (2012). Haematotoxicity of cypermethrin to African catfish, Clarias gariepinus under laboratory conditions. Journal of Environmental Engineering and Technology, 1(2): 20-25.

[26] Nte, M.D., Hart, A.I., Edun, O.M., and Akinrotimi, O.A. (2011). Effect of industrial effluents on haematological parameters of Black jaw tilapia Sarotherodon melanotheron. Continental Journal of Environmental Science, 5(2): 29-37.

[27] Chen, X., Yin D, Hu S, and Hou Y. (2004). Immunotoxicity of penta chlorophenol on macrophage immunity and IgM secretion of the crucian carp (Carassius auratus). J. Bull. Environ. Contam. Toxicol. 73: 153-160.

[28] Akinrotimi, O.A., Aranyo, A.A., and Ibemere, L.F. (2011). Physiological response in Tilapia guineensis subjected to handling stress. Advances in Agriculture science and Engineering Research, 1(2), 34-39.

[29] Akani, N.P. and Gabriel, U.U. (2015). Haematological responses of the African Catfish (Clarias gariepinus) exposed to sublethal concentrations of oil field waste water in Nigeria. Journal of Aquatic Sciences. 30(1B): $207-210$.

[30] Akinrotimi, O.A., Orlu, E.E., and Gabriel, U.U. (2013). Haematological Responses of Tilapia guineensis treated with industrial effluents. Applied Ecology and Environmental Sciences, 1(1): 10-13.

[31] Kori-Siakpere, 0., Ake, J.E.G. and Avworo, U.M. (2006). Sublethal effects of Cadmium on some selected haematological parameters of Heteroclarias (A Hybrid of Heterobranchus bidorsalis and Clarias gariepinus). International Journal of Zoological Research 2:77-83.

[32] George, A.D.I., Akinrotimi O.A.\& Nwokoma,U. K. (2017). Haematological Changes in African Catfish (Clarias gariepinus) Exposed To Atrazine and Metolachlor in the Laboratory. Journal of Fisheries Science.com. 11 (3), 48-54.

[33] Akinrotimi, O.A., Orlu, E.E., \& Gabriel, U.U. (2013). Haematological Responses of Tilapia guineensis treated with industrial effluents. Applied Ecology and Environmental Sciences, 1(1), 10-13.

[34] Banaee, M., Mirvagefei, A. R., Rafei, G. R. and Majazi, A. B., (2008). Effect of sublethal diazinon concentrain on blood plasma biochemistry. Int. J. Environ. Res, 2: 189-198.

[35] Ogundiran, M.A. Fawole, O.O., Adewoye, S.O. and Ayandiran, T.A. (2010). Toxicological impact of detergent effluent on juveniles of African catfish (Clarias gariepinus). Agriculture and Biology Journal of North America. 1(3):330 - 342.

[36] Akinrotimi, O.A., Agokei, E.O., \& Aranyo, A.A. (2012). Changes in haematological parameters of Tilapia guineensis exposed to different salinity levels. Journal of Environmental Engineering and Technology, 1(2), 4-12. 
[37] Akinrotimi, O. A. \& Amachree, D. (2016).Changes in haematological parameters of Tilapia guineensis exposed to different concentrations of detergent under laboratory conditions. Journal of Aquatic Sciences, 31 (1), 95-103.

[38] Akinrotimi, O.A., Opara, J.Y., \& Ibemere, I.F. (2012). Changes in haematological parameters of Tilapia guineensis exposed to different water $\mathrm{pH}$ environment Innovation in Science and Engineering, 2, 9-14.

Citation: Wilfred-Ekprikpo P.C." Effects of Dimethoate on Some Haematological Parameters in Heterobranchus longifilis in the Laboratory", International Journal of Innovative Studies in Aquatic Biology and Fisheries (IJISABF), vol. 7, no.1, pp. 7-13, 2021. http://dx.doi.org/10.20431/2454-7670.0701002

Copyright: (C) 2021 Authors. This is an open-access article distributed under the terms of the Creative Commons Attribution License, which permits unrestricted use, distribution, and reproduction in any medium, provided the original author and source are credited. 